\title{
Influence of livestock grazing on meadow pipit foraging behaviour in upland grassland
}

\author{
Charlotte Vandenberghe ${ }^{\mathrm{a}, \mathrm{b}, *}$, Gina Prior ${ }^{\mathrm{a}, \mathrm{c}}$, Nick A. Littlewood ${ }^{\mathrm{a}}$, Rob Brooker ${ }^{\mathrm{a}}$, \\ Robin Pakeman ${ }^{\mathrm{a}}$
}

${ }^{a}$ The Macaulay Land Use Research Institute, Craigiebuckler, Aberdeen AB15 8QH, UK

${ }^{\mathrm{b}}$ Swiss Federal Research Institute WSL, EPFL - Station 2, 1015 Lausanne, Switzerland

${ }^{\mathrm{c}}$ University of Glasgow, University Avenue, Glasgow G12 8QQ, UK

Received 22 October 2008; accepted 23 March 2009

Available online 12 May 2009

\begin{abstract}
Changes in grazing management are believed to be responsible for declines in populations of birds breeding in grassland over the last decades. The relationships between grazing management regimes, vegetation structure and composition and the availability of invertebrate food resources to passerine birds remain poorly understood. In this study, we investigated the foraging site selection of meadow pipits (Anthus pratensis L.) breeding in high intensity sheep-grazed plots or low intensity mixed (i.e. sheep and cattle)-grazed plots. We sampled above-ground invertebrates, measured vegetation height and density and conducted a vegetation survey in areas where meadow pipits were observed to forage and areas that were randomly selected. Birds foraged in areas with a lower vegetation height and density and in areas containing a lower proportion of the dominant, tussock-forming grass species Molinia caerulea. They did not forage in areas with a total higher invertebrate biomass but at areas with preferred vegetation characteristics invertebrate biomass tended to be higher in foraging sites than random sites. The foraging distance of meadow pipits was higher in the intensively grazed plots. Our findings support the hypothesis that resourceindependent factors such as food accessibility and forager mobility may determine patch selection and are of more importance as selection criteria than food abundance per se. Food accessibility seems to become an even more important selection criterion under high grazing intensity, where prey abundance and size decrease. In our upland grazing system, a low intensity, mixed grazing regime seems to provide a more suitable combination of sward height, plant diversity, structural heterogeneity and food supply for meadow pipit foraging activity compared to a more intensive grazing regime dominated by sheep.
\end{abstract}

(C) 2009 Gesellschaft für Ökologie. Published by Elsevier GmbH. All rights reserved.

\section{Zusammenfassung}

Man nimmt an, dass Veränderungen in der Beweidungswirtschaft während der letzten Jahrzehnte für die Abnahme der Populationen von Vögeln verantwortlich sind, die auf Grünland brüten. Die Beziehungen zwischen verschiedenen Arten der Beweidungswirtschaft, der Vegetationsstruktur und -zusammensetzung und der Verfügbarkeit von Invertebraten-Nahrungsressourcen für Singvögel ist bisher kaum bekannt. In dieser Studie untersuchten wir die

\footnotetext{
*Corresponding author. Current address: Swiss Federal Research Institute WSL, EPFL - Station 2, 1015 Lausanne, Switzerland. Tel.: +41216933767; fax: +41216933905.

E-mail address: charlotte.vandenberghe@wsl.ch (C. Vandenberghe).
} 
Auswahl der Orte für die Nahrungssuche bei Wiesenpiepern (Anthus pratensis L.), die in Flächen brüteten, die in hoher Intensität von Schafen beweidet wurden, oder in Flächen, die in geringer Intensität von Schafen und Rindern beweidet wurden. Wir beprobten die oberirdisch lebenden Invertebraten, maßen die Vegetationshöhe und führten Vegetationsaufnahmen in Flächen durch, in denen Wiesenpieper bei der Nahrungssuche beobachtet wurden und in Flächen, die zufällig ausgewählt wurden. Die Vögel suchten in Flächen mit geringerer Vegetationshöhe und -dichte nach Nahrung und in Flächen, die einen geringeren Anteil des dominanten, Bulten formenden Grases Molinia caerula aufwiesen. Sie suchten nicht in den Flächen mit der höheren Gesamtbiomasse an Invertebraten nach Nahrung, sondern in Flächen, mit den bevorzugten Vegetationsmerkmalen. Die Invertebraten-Biomasse war an den Orten der Nahrungssuche tendenziell höher als in den zufällig ausgewählten Flächen. Die Distanzen bei der Nahrungssuche der Wiesenpieper war in intensiv beweideten Flächen größer. Unsere Ergebnisse stützen die Hypothese, dass von den Ressourcen unabhängige Faktoren, wie die Zugänglichkeit der Nahrung und die Mobiliät der Nahrungssuchenden, die Flächenwahl bestimmen und als Selektionsfaktoren wichtiger sind als die Nahrungsverfügbarkeit an sich. Die Zugänglichkeit der Nahrung scheint bei hohen Beweidungsintensitäten sogar ein noch wichtigerer Faktor zu sein, wenn die Häufigkeit und Größe der Nahrung abnimmt. In unserem Hochland-Beweidungssystem scheint eine gemischte Beweidung bei geringer Intensität im Vergleich zu einer intensiveren Beweidung vor allem durch Schafe den Wiesenpiepern eine geeignetere Kombination aus Höhe, Pflanzendiversität, struktureller Heterogenität und Nahrungsversorgung für die Nahrungssuche zur Verfügung zu stellen.

(C) 2009 Gesellschaft für Ökologie. Published by Elsevier GmbH. All rights reserved.

Keywords: Bird feeding; Cattle; Experimental grazing management; Invertebrate abundance; Molinia-tussocks; Plant composition; Prey availability; Scotland; Sheep; Sward structure

\section{Introduction}

Over the last decades a steady decline in populations of grassland breeding birds has been observed worldwide (Vickery et al. 1999). Several studies relate this decline to changes in grazing practices (Martin \& Possingham 2005; Pearce-Higgins \& Grant 2006; Vickery et al. 2001). Since the inception of the Common Agricultural Policy, several countries have experienced changes in livestock numbers and stocking densities. Within the UK, sheep numbers more than doubled (Fuller \& Gough 1999) and in upland areas this coincided with a switch from mixed grazing regimes toward one dominated by sheep (Sydes \& Miller 1988). In other areas, e.g. the Alps, there has been a long-term trend of pastoral abandonment due to industrialisation in the alpine valleys (Laiolo, Dondero, Ciliento, \& Rolando 2004). Such variation in livestock numbers and species of large herbivore can dramatically alter vegetation structure and plant species composition (Grant, Torvell, Common, Sim, \& Small 1996; Pakeman 2004), and this may have deleterious consequences for groundnesting passerines.

The relationship between management regimes, vegetation structure and composition and the availability of invertebrate food resources to birds is complex and species-specific (McCracken \& Tallowin 2004; Vickery et al. 2001). Although the sensitivity of invertebrates to changes in vegetation characteristics depends on taxon and trophic level (Dennis 2003; Gibson, Brown, Losito, \& McGavin 1992; Pöyry et al. 2006), relaxation of grazing pressure and subsequent increases in vegetation height generally lead to an increase in the overall abundance and biomass of invertebrates (Dennis et al. 2008; Kruess \& Tscharntke 2002). In contrast, the foraging efficiency of many grassland birds decreases as vegetation height increases due to a reduction in forager mobility and prey detectability (Butler \& Gillings 2004). Food accessibility rather than food abundance is a critical factor determining foraging site selection by insectivorous birds (Atkinson, Buckingham, \& Morris 2004). It is hypothesised, therefore, that the optimal habitat for passerine birds represents a trade-off between food abundance and foraging ability (Atkinson et al. 2005), but experimental evidence for this mechanism remains scarce. Furthermore, Brickle, Harper, Aebischer, and Cockayne (2000) found that corn buntings (Miliaria calandra) travelled further to forage when invertebrate abundance was low close to the nest. Foraging distance might therefore increase in intensively grazed areas. Exploring the relationships between birds and their food resources is fundamental to understand their foraging patch selection and the possible consequences of agricultural reform on bird populations.

A large-scale experimental manipulation of sheep and cattle grazing was established in an upland area of Scotland in 2003. This system has been used to explore linkages between grazing management, sward structure, plant composition, invertebrate abundance and foraging site selection of a common insectivorous passerine, the meadow pipit (Anthus pratensis L.). The livestock grazing treatments have initiated changes, and hence differences, in vegetation structure rather than plant species composition (R. Pakeman, unpublished data) 
and in the abundance and biomass of invertebrates (Dennis et al. 2008; Littlewood 2008). The experiment has also demonstrated that the egg size (Evans, Redpath, Evans, Elston, \& Dennis 2005) and breeding abundance (Evans et al. 2006) of meadow pipits was positively affected by a low intensity, mixed grazing regime compared to sheep grazing at the same or higher intensity. More recently, Douglas, Evans, and Redpath (2008) investigated the foraging behaviour of meadow pipits under high intensity grazing by sheep, and found that individuals selected foraging sites within $80 \mathrm{~m}$ of their nest with low vegetation height and density but a significantly higher arthropod biomass than in random areas. The next question to address is whether foraging selection criteria are the same under different grazing intensities and livestock types.

In this study, we investigated the foraging site selection of meadow pipits breeding in high intensity sheep-grazed plots or low intensity mixed (i.e. sheep and cattle)-grazed plots. More specifically we measured how vegetation characteristics and invertebrate abundance and biomass differed between areas where meadow pipits were observed to forage and areas that were randomly selected. We hypothesised that adult meadow pipits will optimise total food uptake, which is a product of prey abundance and accessibility, when provisioning nestlings by (1) selecting foraging sites of similar vegetation height, density and diversity under both high intensity sheep grazing and low intensity mixed grazing, (2) foraging in sites with a relatively smaller decrease of invertebrate supply with increasing livestock densities and (3) foraging further away from the nest in the high intensity grazed treatments.

\section{Methods and materials}

\section{Study area}

The study was carried out in June 2007 at the Glen Finglas estate (4039ha) in central Scotland (200-500 $\mathrm{m}$ a.s.1., $\left.56^{\circ} 16^{\prime} \mathrm{N} 4^{\circ} 24^{\prime} \mathrm{W}\right)$. The area was grazed by sheep and cattle, is typical of many upland parts of Scotland, and had not been subject to pesticide or fertiliser application. The vegetation consisted of a fine-grained mosaic of Molinia caerulea-Potentilla erecta mire, Juncus effusus/acutiflorus-Galium palustre rush pasture and Festuca oviana-Agrostis capillaris-Galium saxatile grassland communities (see Dennis et al. (2008) for a more detailed description) defined by the presence of tussocks constructed of M. caerulea, Nardus stricta and Juncus effusus (nomenclature follows Tutin et al. (1964-1980)).

In 2003 a grazing experiment was established across three sites within Glen Finglas, each containing two replicate blocks. Each block was composed of four plots $(\sim 3$ ha in size) with four grazing treatments randomly assigned as follows: (1) High-Sheep (High-S): nine sheep/plot: grazing at the current commercial rate for these types of grasslands, $2.72 \mathrm{ewes} \mathrm{ha}^{-1} \mathrm{yr}^{-1}$ (2) LowSheep (Low-S): three sheep/plot: grazing at one-third of the commercial rate, 0.9 ewe ha ${ }^{-1} \mathrm{yr}^{-1}$, (3) Low-Sheep and Cattle (Low-SC): grazing with two sheep and two cows each with a suckling calf at an equivalent off-take to the Low-S treatment and (4) None: no livestock grazing. Low-S represented the previous grazing regime. Sheep remained in the plots throughout the year and were only removed for normal farm operations and during periods of severe weather. Cattle were added to the Low-SC treatments in September and October of each year.

\section{Foraging (FS) and random squares (RS)}

Meadow pipit nests were found by behavioural observation or by flushing incubating females from the nest. Nests were only located in two of the three sites as a high nest predation rate $(\sim 40 \%, G$. Prior, unpublished data) excluded the third site from analysis. In order to obtain a sufficient number of replicates, nests in only the High-S $(n=5)$ and Low-SC $(n=6)$ treatments were used in this study. To reduce temporal variability in the foraging and provisioning behaviour of adult birds, nests were selected that contained chicks between 5 and 8 days of age.

Foraging behaviour was observed using binoculars $(10 \times 42)$, for $1 \mathrm{~h}$, at a minimum distance of $80 \mathrm{~m}$ from the nest. All observations were conducted in dry weather between 0800 and $1400 \mathrm{~h}$. A foraging point was defined as the point from which a meadow pipit was observed to fly toward the nest carrying food. The distance and orientation of each foraging point from the focal nest was recorded. Foraging points were paired with random points. Random points were positioned at a random angle of orientation but at the same distance from the nest as their related foraging point (Fig. 1). Quadrats of $2 \times 2 \mathrm{~m}$ (hereafter called squares) were orientated following cardinal directions with foraging or random points located centrally. In total, we laid out four paired foraging and random squares related to each of the 11 nests.

\section{Vegetation and invertebrate sampling}

In each square ( $n=88)$, we (1) sampled above-ground (foliar) invertebrates, (2) measured vegetation height and density and (3) conducted a vegetation survey. To reduce the level of disturbance at the nest, vegetation and invertebrate sampling protocols were not conducted on the same day as behavioural observations and breaks 


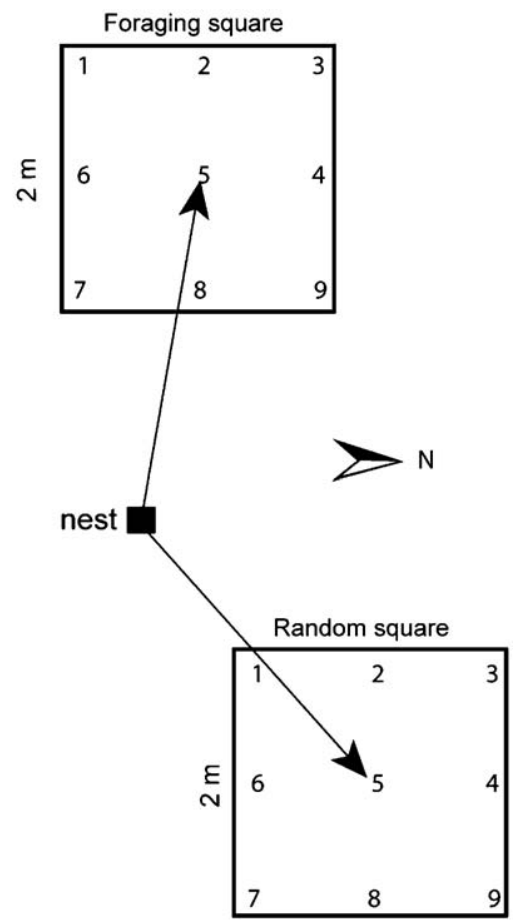

Fig. 1. Sampling design: example of one foraging square (FS) and its paired random square (RS) in relation to a focal nest. The nine locations at which vegetation height, vegetation density and invertebrate suction samples were taken are noted.

were included throughout the sampling period to allow parent birds to attend the nest. Additional delays were also experienced as invertebrates could only be collected during periods of dry weather. As a result, sampling was conducted between 2 and 9 days after behavioural observations were completed.

In each FS and RS, a grid of nine points was used to standardise vegetation measurements and locations for invertebrate sampling. Above-ground invertebrates were sampled using a leaf blower $(9555 \mathrm{LW}$ blower/shredder vacuum, Little Wonder, Southampton, PA, USA) with a nozzle area of $0.00931 \mathrm{~m}^{2}$. A $5 \mathrm{~s}$-suction was made at each of the nine points to give a $45 \mathrm{~s}$ pooled sample per square (Fig. 1). Samples were transferred to plastic bags and frozen on the same day, for processing at a later date. Vegetation height and density were measured at the same nine standard points in each square. Vegetation height was measured using the "drop-disc method" (Holmes 1974) whereby a plastic disc $(15 \mathrm{~cm}$ diameter, $13.2 \mathrm{~g}$ ) with a central slot was lowered down a vertically held ruler, measuring the height of the vegetation where the disc came to rest. Vegetation density was measured by placing a banded measuring stick vertically through the vegetation and recording the lowest $5 \mathrm{~cm}$ interval visible from a height of $1 \mathrm{~m}$. A botanical survey was then carried out in each FS and RS. Species were not always fully (binomial) identified but placed within a genus
Table 1. The 20 most common plant species or genera in foraging (FS) and random (RS) squares.

\begin{tabular}{|c|c|c|c|}
\hline Species & FS cover & RS cover & \\
\hline Molinia caerulea & 49.9 & 60.1 & (1) \\
\hline Festuca spp. & 19.8 & 12.3 & (5) \\
\hline Carex spp. & 19.1 & 14.5 & (4) \\
\hline Potentilla erecta & 16.0 & 14.8 & (3) \\
\hline Trichophorum cespitosum & 13.5 & 8.5 & (8) \\
\hline Nardus stricta & 12.0 & 9.7 & (6) \\
\hline Anthoxanthum odoratum & 9.7 & 8.7 & (7) \\
\hline Vaccinium myrtillus & 8.4 & 7.5 & $(10)$ \\
\hline Narthecium ossifragum & 7.8 & 8.4 & (9) \\
\hline Myrica gale & 6.4 & 5.5 & $(12)$ \\
\hline Galium spp. & 6.2 & 4.5 & $(14)$ \\
\hline Juncus acutiflorus & 5.9 & 15.1 & $(2)$ \\
\hline Deschampsia flexuosa & 5.9 & 2.8 & $(20)$ \\
\hline Luzula spp. & 5.2 & 4.4 & (16) \\
\hline Holcus lanatus & 5.2 & 4.5 & $(15)$ \\
\hline Ranunculus spp. & 5.1 & 3.1 & (19) \\
\hline Pteridium aquilinum & 4.9 & 7.2 & $(11)$ \\
\hline Bryophyta & 3.8 & 3.8 & (17) \\
\hline Parnassia palustris & 3.6 & 4.9 & (13) \\
\hline Plantago spp. ${ }^{\mathrm{a}}$ & 2.9 & & \\
\hline Juncus squarrosus $^{\mathrm{a}}$ & & 3.6 & (18) \\
\hline Species richness & $13.9 \pm 0.58$ & $13.5 \pm 0.53$ & \\
\hline Shannon diversity & $2.22 \pm 0.05$ & $2.07 \pm 0.05$ & \\
\hline
\end{tabular}

Cover $=$ average absolute cover (expressed as percentage) of each species or genus within a $2 \times 2 \mathrm{~m}(n=44)$. Rank numbers, for RS cover values, are given in brackets. Average species richness and Shannon diversity indices (mean $\pm 1 \mathrm{SE}$ ) are given for both square types.

${ }^{\text {a }}$ Plant species or genus present in only one square type.

(e.g. Carex spp., see Table 1) which was subsequently treated as a pseudospecies. Mosses were classified as Bryophyta. The average cover of each species or genus within a square was estimated as proportions $(0.025$ : $<5 \%$; 0.15: 5-25\%; 0.375: 26-50\%；0.625: 51-75\%; 0.875: 76-100\%). The Shannon diversity index of each square was calculated as $H=-\sum_{i=1}^{S} P_{i} \ln p_{i}$, where $S$ is the number of species and $p_{i}$ the fraction of the population abundance corresponding to species $i$.

Seven invertebrate groups have been recognized as important in the diet of upland breeding birds (Buchanan, Grant, Sanderson, \& Pearce-Higgins 2006): Araneae, Coleoptera, Hymenoptera, Diptera, Heteroptera, Auchenorryncha and Lepidoptera. All invertebrates larger than $1.5 \mathrm{~mm}$ in length (smaller items were not fed to the chicks, G. Prior, pers. comm.) were counted and assigned to one of these seven groups using a binocular microscope and then stored in $70 \%$ ethanol. Total invertebrate abundance represented the sum number of all individuals of the seven groups per square. Individuals of each invertebrate group from each square were removed from ethanol, air dried for $1 \mathrm{~h}$ and weighed together $(0.0001 \mathrm{~g}$ precision $)$ to provide a 
measure of invertebrate biomass. Total invertebrate biomass represented the sum of the invertebrate groupbiomasses per square. The mean mass per individual of each invertebrate group per square was calculated by dividing invertebrate biomass by invertebrate abundance.

\section{Statistical analyses}

The effects of grazing treatment (High-S and LowSC) and square-type (FS and RS) and their interaction on vegetation height and vegetation density $(n=88)$ were tested using a linear mixed-effects model with residual maximum likelihood estimation (REML: Venables \& Ripley 2002). An average of the nine vegetation height and density sub-samples per square was used in the analyses with a nested design structure (site/block/ nest/square) specified as a random effect. The difference in plant species richness, Shannon diversity index and average absolute cover of the most abundant species (i.e. $M$. caerulea) between both FS and RS was tested using REML with the same design structure.

Non-parametric Kruskal-Wallis tests were used to compare the number of invertebrate groups between grazing treatments and between square-types because assumptions for parametric tests were not fulfilled. The effects of grazing treatment and square-type and their interactions on total invertebrate abundance (number of individuals from the nine locations per square) and total biomass ( $\mathrm{mg}$ of invertebrates from the nine locations per square) $(n=88)$ were tested using REML with the same design structure as described for the vegetation measurements. In the same way, the effect of invertebrate group and square-type and their interaction on mean invertebrate abundance $(n=564)$, mean invertebrate biomass $(n=564)$ and mean mass per individual mass $(n=564)$ were tested using REML. These three response variables were log-transformed to reduce heteroscedasticity. The total number of observations was lower than 616 (i.e. $7 \times 88)$ since Lepidoptera $(n=38)$, Heteroptera $(n=87)$ and Coleoptera $(n=87)$ were not present in each of the sampled squares.

In order to link foraging behaviour, invertebrates and vegetation, the effect of vegetation height (divided into three classes) and the average absolute cover of the most abundant species (i.e. M. caerulea, divided into two classes) on total invertebrate biomass, for both FS and RS, was tested using REML. Total biomass was logtransformed.

The fixed effect of grazing treatment on foraging distance from the nest $(n=44)$ was tested using REML. A nested design structure (site/block/nest) was specified as a random effect. All statistical analyses were performed with R, version 2.5.1 (R Foundation for Statistical Computing 2007).

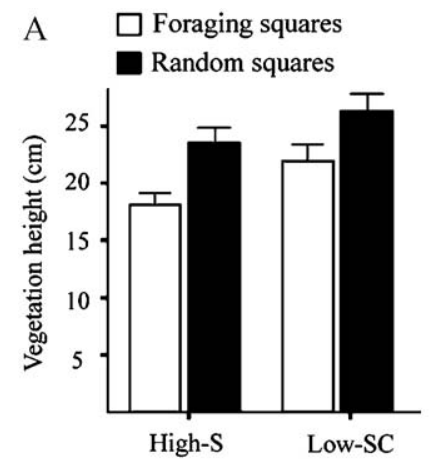

B

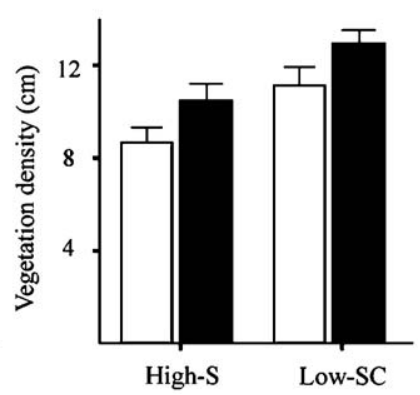

Fig. 2. Effects of grazing treatment (High-Sheep (High-S) and Low-Sheep-Cattle (Low-SC)) and square-type (foraging and random) on (A) vegetation height $(\mathrm{cm})$ and $(\mathrm{B})$ vegetation density (cm) (mean \pm 1 SE; High-S: $n=20$ and Low-SC: $n=24)$.

\section{Results}

\section{Vegetation characteristics and foraging distance}

Vegetation height $\left(F_{1,53}: 30.0, p<0.0001\right)$ and density $\left(F_{1,53}: 34.3, p<0.0001\right)$ were significantly higher in LowSC than in High-S, and vegetation height $\left(F_{1,53}: 20.6\right.$, $p<0.001)$ and density $\left(F_{1,53}: 8.7, p<0.01\right)$ were significantly higher in random squares than in foraging squares under both grazing treatments (Fig. 2). No significant interactions between grazing treatment and square-type were found, indicating that differences in vegetation height and density between FS and RS were similar in both grazing treatments.

The 20 most common plant species or pseudospecies of FS and RS only differed in one species (Table 1). FS represented a more diverse community than RS (Shannon diversity index: $F_{1,55}: 5.99, p<0.05$ ). In particular the mean proportion of the dominant species, i.e. $M$. caerulea, was significantly lower in FS $(0.49 \pm 0.04)$ than in RS $(0.60 \pm 0.04)\left(F_{1,55}: 4.91\right.$, $p<0.05)$. However, besides Molinia, only three species or pseudospecies differed by more than $5 \%$ in mean absolute cover between square-types, namely Festuca spp., Juncus acutiflorus and Trichophorum cepitosum (Table 1). Species richness was equal between FS and $\mathrm{RS}\left(F_{1,55}: 0.50, p=0.48\right)$.

Meadow pipits foraged significantly further away from the nest in High-S $(29.3 \mathrm{~m} \pm 2.89$, mean $\pm 1 \mathrm{SE})$ than in Low-SC $(15.1 \mathrm{~m} \pm 1.85)\left(F_{1,35}: 12.3, p<0.01\right)$.

\section{Invertebrates in relation to livestock grazing and bird foraging}

No significant differences in invertebrate-group composition $(n=7)$ between grazing intensities $\left(\chi^{2}=1.19\right.$, 
d.f. $=1, p=0.27)$ and FS and RS $\left(\chi^{2}=0.089\right.$, d.f. $=1, p=0.76$ ) were found. The total abundance of invertebrates was significantly higher in Low-SC than in High-S $\left(F_{1,53}: 4.42, p<0.05\right)$ but did not differ significantly between square-types $\left(F_{1,53}: 0.01, p=0.9\right)$ (Fig. 3). The total biomass of invertebrates was significantly higher in Low-SC than in High-S $\left(F_{1,53}\right.$ : $29.5, p<0.0001)$ but did not differ significantly between square-types $\left(F_{1,53}: 0.08, p=0.78\right)$ (Fig. 3$)$. No significant interactions between grazing treatment and square-type were found for invertebrate abundance $\left(F_{1,53}: 1.78, p=0.19\right)$ and invertebrate biomass $\left(F_{1,53}\right.$ : $0.59, p=0.44)$.

Invertebrate groups differed significantly in abundance $\left(F_{6,519}: 117, p<0.0001\right)$, total biomass $\left(F_{6,519}: 31\right.$, $p<0.0001)$, and mass per individual $\left(F_{6,519}\right.$ : 23 ,
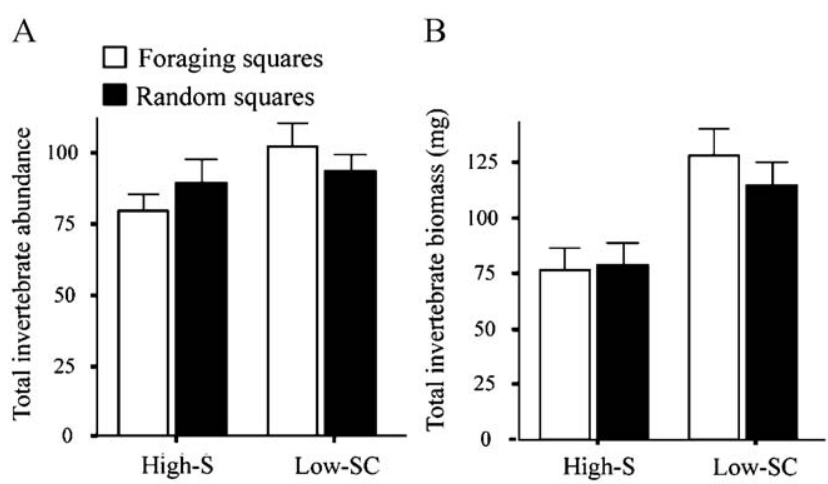

Fig. 3. Effects of grazing treatment (High-Sheep (High-S) and Low-Sheep-Cattle (Low-SC)) and square-type (foraging and random) on (A) total invertebrate abundance (number of individuals from nine locations per square) and (B) total invertebrate biomass ( $\mathrm{mg}$ from nine locations per square) (mean \pm 1 SE; High-S: $n=20$ and Low-SC: $n=24$ ). $p<0.0001$ ) (Fig. 4). However, no significant differences were found between FS and RS, although the mass per individual tended to increase in FS for Coleoptera, Hymenoptera, Heteroptera and Lepidoptera. Auchenorryncha was the only group that had lower abundance, biomass and mass per individual in FS (Fig. 4). The interaction between invertebrate group and squaretype was marginally significant for mean abundance $\left(F_{6,519}: 1.99, p=0.07\right)$ but not significant for mean biomass $\left(F_{6,519}: 1.41, p=0.21\right)$ and mean mass per individual $\left(F_{6,519}: 0.87, p=0.51\right)$ (Fig. 4$)$.

Total invertebrate biomass increased significantly with vegetation height class $\left(F_{2,51}: 9.58, p<0.001\right)$ (Fig. 5A). The difference between square-types was not significant $\left(F_{1,51}: 0.07, p=0.79\right)$ and no significant interaction was found between square-type and vegeta-
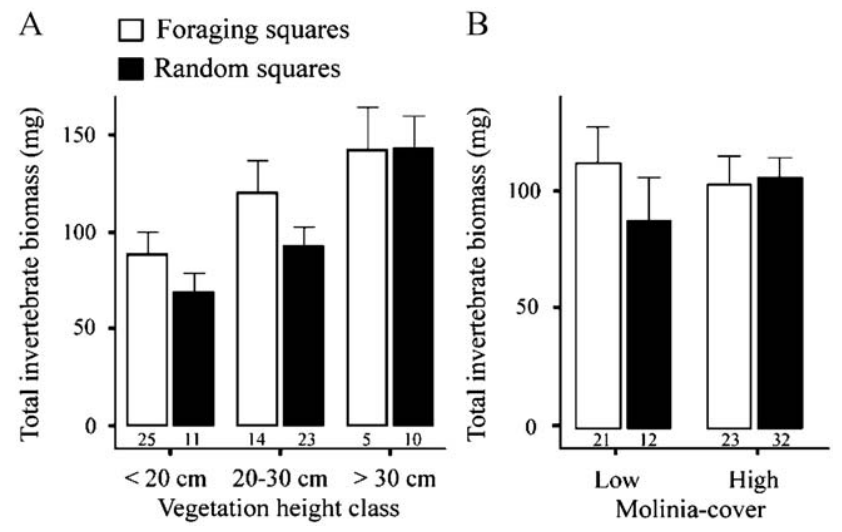

Fig. 5. Effects of square-type (foraging and random) and (A) vegetation height class and (B) Molinia-cover (Low: proportion per square $<0.5$ and High: proportion per square $>0.5$ ) on total invertebrate biomass ( $\mathrm{mg}$ from nine locations per square) (mean $\pm 1 \mathrm{SE}, n$ noted).
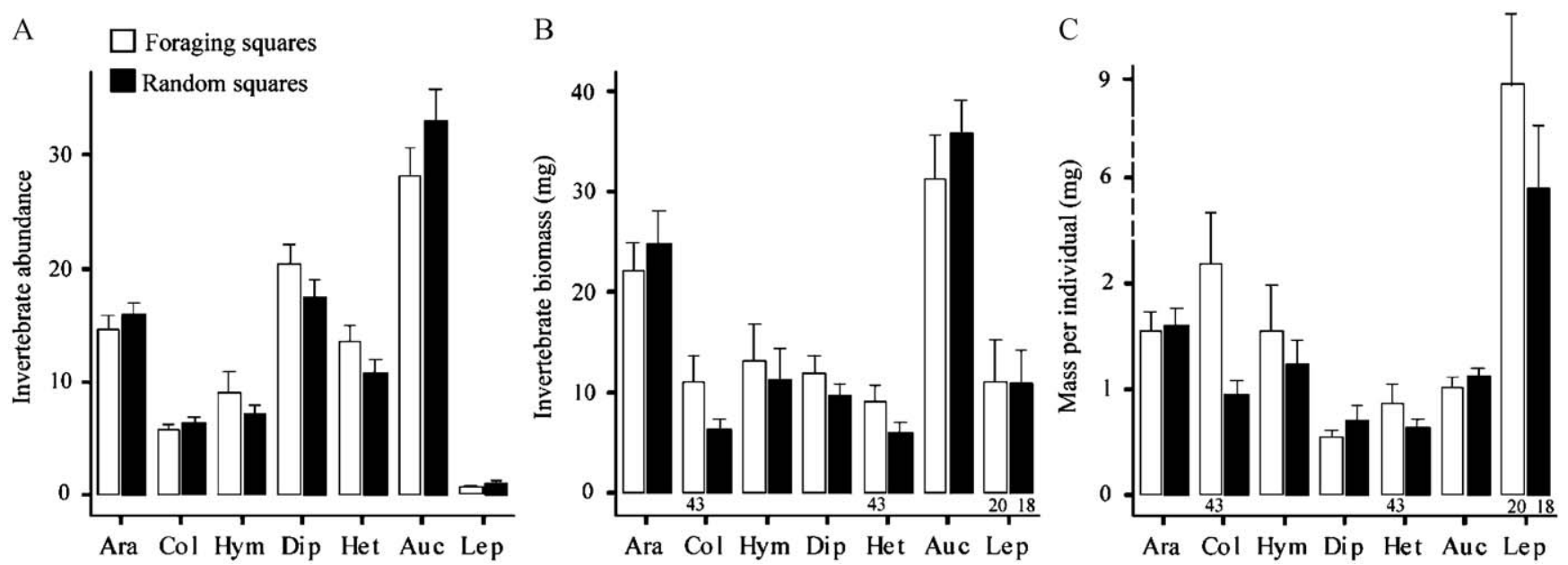

Fig. 4. (A) Invertebrate abundance (number of individuals from nine locations per square), (B) biomass (mg from nine locations per square), and (C) mass per individual (mg; biomass/number of individuals) in foraging and random squares for each of the seven identified groups. Data presented are means $( \pm 1 \mathrm{SE}, n=44$ per treatment; exceptions are noted). 
tion height class $\left(F_{2,51}: 0.37, p=0.69\right)$. However, the difference between FS and RS in total invertebrate biomass tended to decrease with increased vegetation height (Fig. 5A). Although no significant interaction was found between Molinia-cover and square-type $\left(F_{2,53}: 2.57, p<0.1\right)$, FS tended to contain a greater invertebrate biomass than $\mathrm{RS}$ at low proportion of Molinia (Fig. 5B).

\section{Discussion}

Meadow pipits selected comparatively short vegetation for foraging at our study site. This concurs with the work of Douglas et al. (2008) at the same site. Furthermore, birds foraged in patches with a more diverse and less dense sward structure, and with a lower proportion of the dominant plant species $M$. caerulea. It should be noted that any significant result from this study represents a strong pattern, as random squares necessarily include areas where meadow pipits may, or may not, forage. Contrary to our first hypothesis, meadow pipits did not select swards similar in height and density under both the high and low intensity grazing treatments. Instead, birds foraged in areas with lower vegetation height and density as grazing intensity increased.

In contrast to our second hypothesis we found no evidence that in the intensive-sheep grazing plots, birds foraged in patches that had undergone the smallest decrease in overall invertebrate supply (invertebrate abundance and biomass) (Fig. 3). This is related to the unexpected outcome of our first hypothesis but is a logical result as the abundance and biomass of foliar arthropods decreased significantly with decreasing vegetation height, as shown by other studies (Britschgi, Spaar, \& Arlettaz 2006; Dennis et al. 2008; Kruess \& Tscharntke 2002; Littlewood 2008). However, foraging squares did tend to contain more invertebrate biomass than random squares at the preferred vegetation characteristics, i.e. lower vegetation height and density and low proportions of Molinia (Fig. 5). Yet, in vegetation higher than $30 \mathrm{~cm}$ and with a large proportion of Molinia the apparent ability of birds to select patches with a higher invertebrate biomass disappeared. Thus, meadow pipits did not forage in areas with a total higher invertebrate biomass but selected sites according to a combination of attributes. A number of studies demonstrate that the body size of a range of invertebrate groups decreases in intensively managed grasslands (e.g. Blake, Foster, Eyre, \& Luff 1994). In our study, total invertebrate biomass was more negatively influenced by high grazing disturbance than invertebrate abundance, which suggests the intensively grazed plots contained a higher proportion of small invertebrates. If the size distribution of prey-items reduces the suitability of the sward as a foraging resource for birds, food accessibility might become an even more important selection criterion under high grazing pressure. This mechanism might explain partly why meadow pipits foraged in areas with an absolute lower vegetation height and density as grazing intensity increased. Our findings support the hypothesis that resource-independent factors such as food accessibility and forager mobility may determine patch selection and are of more importance as selection criteria than food abundance per se (Atkinson et al. 2005; Butler \& Gillings 2004; Douglas et al. 2008).

Intensive grazing management may not only indirectly influence the breeding performance of passerine birds through changes in total insect abundance and biomass but also via changes in insect diversity and the availability of potential food items (Kruess \& Tscharntke 2002; Pöyry et al. 2006). We were unable to conduct a detailed investigation of the effects of grazing intensity and vegetation characteristics on specific groups or species of invertebrates because our single suction sampling method captured only a component of the invertebrates that utilised the sward (Standen 2000). It is, however, an effective method of sampling invertebrate assemblages in grasslands and it did allow a consistent approach in all sampled squares (Brook, Woodcock, Sinka, \& Vanbergen 2008). All seven of the identified invertebrate groups were present with approximately the same abundance and biomass in foraging and random squares. Individual mass did, however, tend to increase in foraging squares for Coleoptera, Hymenoptera, Heteroptera and Lepidoptera. Lepidoptera and soil-dwelling invertebrates, such as leatherjackets (Tipulidae larvae), form a major component in the diet of nestling meadow pipits (Douglas et al. 2008; Evans et al. 2005) as they represent both large biomass and high nutrient quality. The selection of short vegetation by foraging adults may be partly due to the increased detectability of leatherjackets (Atkinson et al. 2004). However, we were unable to statistically investigate this relationship because our sampling efforts indicated that leatherjacket density was both low and highly variable. This could be a true reflection of prey abundance, or an artefact of prey depletion that may have occurred during the time lag between initial observations of foraging behaviour and the initiation of invertebrate sampling. Further effort is needed to identify and correct the influence - if any - of short-term dynamics of insect populations on the interactions between bird foraging behaviour on a particular day and insect abundance and biomass pattern sampled at a later date. Invertebrate sampling methods which focus more precisely on species selected by passerine birds will certainly help to provide more detailed information on their foraging selection criteria. 
As expected, the foraging distance of meadow pipits increased in the intensively grazed plots. This could be due to less successful foraging activity linked to a large proportion of unsuitable small prey items and/or the need for increased search effort across multiple locations before returning to the nest. In a study of the breeding ecology of another insectivorous passerine, the whinchat Saxicola rubetra, in an Alpine meadowland, it was concluded that longer foraging trips indicated the presence of poor breeding habitat (Britschgi et al. 2006). Increased foraging distances may result in extra fitness costs and an increased risk of predation (Muchai, Lens, \& Bennum 2002) for parents breeding in intensively managed habitats, and may explain the lower abundance of meadow pipits in the high intensity sheep grazed plots at Glen Finglas (Evans et al. 2006). Additional research should quantify provisioning rates, prey biomass and fledging rate between grazing treatments in order to provide insight into the effects of grazing intensity on the condition of birds during the breeding season.

In the British uplands, meadow pipits occur at high densities in habitats comprising a mosaic of grass and dwarf shrubs, such as heather. A disappearance of these mosaics would prove detrimental to meadow pipits, and other bird species, which rely on heterogeneous vegetation for nesting cover and food during the breeding season (Vanhinsbergh \& Chamberlain 2001). Over recent decades, substantial increases in Molinia, at the expense of dwarf shrub vegetation, have been observed in Europe (e.g. UK, Holland) due to inappropriate burning and grazing regimes (Marrs, Philips, Todd, Ghorbani, \& Le Duc 2004). The utilisation of Molinia by livestock, in particular by cattle which are less selective than sheep, increases plant diversity (Grant et al. 1996) and consequently habitat quality for insectivorous birds. The presence of tussock forming grasses may, however, constitute an important feature of grassland swards for foraging birds through decreased predation risk (Muchai et al. 2002) and increased invertebrate food supply (Dennis, Young, \& Gordon 1998; this study). In our system, a low intensity, mixed grazing regime seems to provide a more suitable combination of sward height, plant diversity, structural heterogeneity and food supply for meadow pipit foraging activity compared to a more intensive sheeponly grazing regime.

\section{Acknowledgements}

We thank Gabor Pozsgai for advice about invertebrate sampling, Jane DeGabriel and Brian Pickles for assistance with invertebrate processing, Unai Castillo for field assistance, Darren Evans for useful comments on experimental design and sampling methods, and
Simon Thirgood and Stephen Redpath for valuable comments on the manuscript. We acknowledge the support of The Woodland Trust, Scotland, for permission to use their land and for managing the livestock. C.V. was financially supported by a Swiss National Science Foundation grant and G.P. by a Macaulay Development Trust studentship. The study was conducted as part of a collaborative project (The Glen Finglas Project) funded by the Scottish Government Rural and Environment Research and Analysis Directorate (RERAD).

\section{References}

Atkinson, P. W., Buckingham, D., \& Morris, A. J. (2004). What factors determine where invertebrate-feeding birds forage in dry agricultural grasslands? Ibis, 146, 99-107.

Atkinson, P. W., Fuller, R. J., Vickery, J. A., Conway, G. J., Tallowin, J. R. B., Smith, R. E. N., et al. (2005). Influence of agricultural management, sward structure and food resources on grassland field use by birds in lowland England. Journal of Applied Ecology, 42, 932-942.

Blake, S., Foster, G. N., Eyre, M. D., \& Luff, M. L. (1994). Effects of habitat type and grassland management practices on the body size and distribution of carabid beetles. Pedobiologia, 38, 502-512.

Brickle, N. W., Harper, D. G. C., Aebischer, N. J., \& Cockayne, S. H. (2000). Effects of agricultural intensification on the breeding success of corn buntings Miliaria calandra. Journal of Applied Ecology, 37, 742-755.

Britschgi, A., Spaar, R., \& Arlettaz, R. (2006). Impact of grassland farming intensification on the breeding ecology of an indicator insectivorous passerine, the Whinchat Saxicola rubetra: lessons for overall Alpine meadowland management. Biological Conservation, 130, 193-205.

Brook, A. J., Woodcock, B. A., Sinka, M., \& Vanbergen, A. J. (2008). Experimental verification of suction sampler capture efficiency in grasslands of differing vegetation height and structure. Journal of Applied Ecology, 45, 1357-1363.

Buchanan, G. M., Grant, M. C., Sanderson, R. A., \& PearceHiggins, J. M. (2006). The contribution of invertebrate taxa to moorland bird diets and the potential implication of land-use management. Ibis, 148, 615-628.

Butler, S. J., \& Gillings, S. (2004). Quantifying the effects of habitat structure on prey detectability and accessibility to farmland birds. Ibis, 146, 123-130.

Dennis, P. (2003). Sensitivity of upland arthropod diversity to livestock grazing, vegetation structure and landform. Food, Agriculture \& Environment, 1, 301-307.

Dennis, P., Skartveit, J., McCracken, D. I., Pakeman, R. J., Beaton, K., Kunaver, A., et al. (2008). The effects of livestock grazing on foliar arthropods associated with bird diet in upland grasslands of Scotland. Journal of Applied Ecology, 45, 279-287.

Dennis, P., Young, M. R., \& Gordon, I. J. (1998). Distribution and abundance of small insects and arachnids in relation to structural heterogeneity of grazed, indigenous grasslands. Ecological Entomology, 23, 253-264. 
Douglas, D. J. T., Evans, D. M., \& Redpath, S. M. (2008). Foraging behaviour of meadow pipits Anthus pratensis provisioning nestlings on intensively grazed moorland. Bird Study, 55, 290-296.

Evans, D. M., Redpath, S. M., Evans, S. A., Elston, D. A., \& Dennis, P. (2005). Livestock grazing affects the egg size of an insectivorous passerine. Biology Letters, 1, 322-325.

Evans, D. M., Redpath, S. M., Evans, S. A., Elston, D. A., Gardner, C. J., Dennis, P., et al. (2006). Low intensity, mixed livestock grazing improves the breeding abundance of a common insectivorous passerine. Biology Letters, 2, 636-638.

Fuller, R. J., \& Gough, S. J. (1999). Changes in sheep numbers in Britain: Implications for bird populations. Biological Conservation, 91, 73-89.

Gibson, C. W. D., Brown, V. K., Losito, L., \& McGavin, G. C. (1992). The response of invertebrate assemblies to grazing. Ecography, 15, 166-176.

Grant, S. A., Torvell, L., Common, T. G., Sim, E. M., \& Small, J. L. (1996). Controlled grazing studies on Molinia grassland: Effects of different seasonal patterns and levels of defoliation on Molinia growth and responses of swards to controlled grazing. Journal of Applied Ecology, 33, 1267-1280.

Holmes, C. W. (1974). Dairy farming annual. Palmerston North, New Zealand: Massey University.

Kruess, A., \& Tscharntke, T. (2002). Contrasting responses of plant and insect diversity to variation in grazing intensity. Biological Conservation, 106, 293-302.

Laiolo, P., Dondero, F., Ciliento, E., \& Rolando, A. (2004). Consequences of pastoral abandonment for the structure and diversity of the alpine avifauna. Journal of Applied Ecology, 41, 294-304.

Littlewood, N. (2008). Grazing impacts on moth diversity and abundance on a Scottish upland estate. Insect Conservation and Diversity, 1, 151-160.

Marrs, R. H., Philips, J. D. P., Todd, P. A., Ghorbani, J., \& Le Duc, M. G. (2004). Control of Molinia caerulea on upland moors. Journal of Applied Ecology, 41, 398-411.

Martin, T. G., \& Possingham, H. P. (2005). Predicting the impact of livestock grazing on birds using foraging height data. Journal of Applied Ecology, 42, 400-408.

McCracken, D. I., \& Tallowin, J. R. (2004). Swards and structure: The interaction between farming practices and bird food resources in lowland grasslands. Ibis, 146, 108-114.
Muchai, M., Lens, L., \& Bennum, L. (2002). Habitat selection and conservation of Sharpe's longclaw (Macronyx sharpei), a threatened Kenyan grassland endemic. Biological Conservation, 105, 271-277.

Pakeman, R. (2004). Consistency of plant species and trait responses to grazing along a productivity gradient: A multisite analysis. Journal of Ecology, 92, 893-905.

Pearce-Higgins, J. W., \& Grant, M. C. (2006). Relationships between bird abundance and the composition and structure of moorland vegetation. Bird Study, 53, 112-125.

Pöyry, J., Luoto, M., Paukkunen, J., Pykälä, J., Raatikainen, K., \& Kuussaari, M. (2006). Different responses of plants and herbivore insects to a gradient of vegetation height: An indicator of the vertebrate grazing intensity and successional age. Oikos, 115, 401-412.

R Development Core Team. (2007). R: A language and environment for statistical computing. Version 2.5.1, R Foundation for Statistical Computing, Vienna, Austria, < http://www.R-project.org/ $>$.

Standen, V. (2000). The adequacy of collecting techniques for estimating species richness of grassland invertebrates. Journal of Applied Ecology, 37, 884-893.

Sydes, C., \& Miller, G. R. (1988). Range management and nature conservation in the British uplands. In M. B. Usher, \& D. B. A. Thompson (Eds.), Ecological change in the uplands (pp. 323-337). Oxford: Blackwell Scientific Publications.

Tutin, T. G., Heywood, V. H., Burges, N. A., Moore, D. D., Valentine, D. H., Walters, S. M., et al. (1964-1980). Flora Europaea, Vols. 1-5. Cambridge: Cambridge University Press.

Vanhinsbergh, D. P., \& Chamberlain, D. E. (2001). Habitat associations of breeding meadow pipits Anthus pratensis in the British uplands. Bird Study, 48, 159-172.

Venables, W. N., \& Ripley, B. D. (2002). Modern applied statistics with $S$ (4th ed). New York: Springer.

Vickery, J. A., Tallowin, J. R., Feber, R. E., Asteraki, E. J., Atkinson, P. W., Fuller, R. J., et al. (2001). The management of lowland neutral grasslands in Britain: Effects of agricultural practices on birds and their food resources. Journal of Applied Ecology, 38, 647-664.

Vickery, P. D., Tubaro, P. L., da Silva, J. M. C., Peterjohn, P. G., Herkert, J. R., \& Calvalcanti, R. B. (1999). Conservation of grassland birds in the western hemisphere. In P. D. Vickery, \& J. R. Herkert (Eds.), Conservation of grassland birds of the western hemisphere, Vol. 19 (pp. 2-26). California: Cooper Ornithological Society. 